\title{
Isolation and Biochemical Characterization of Escherichia coli from Bovine Mastitic Milk
}

\author{
B.N. Paramesh*, A. Basavaraj, P. Suryakanth, B. Abhilash and M. Revappayya \\ Department of Veterinary Microbiology, Veterinary College, Bidar, India \\ *Corresponding author
}

\section{A B S T R A C T}

\section{Keywords}

Bovine mastitis, Milk, Escherichia coli, Biochemical characterization

\section{Article Info}

Accepted: 06 June 2018 Available Online: 10 July 2018
Mastitis is an inflammation of udder which is mainly caused by coliforms and other microorganism. It is a most economically important disease in bovines. In the present study a total number of 100 bovine mastitis milk samples were collected. All the samples were inoculated into enrichment broth which was further cultured on Mac-Conkey plate. Out of these 42 samples that were showing lactose fermentation were further streaked on EMB selective agar plates. Colonies showing metallic sheen were processed for biochemical analysis. Based on the morphological, cultural and biochemical characterization indicated that 40 isolates were E. coli. E. coli is one of the most important bacterium of coliform group that causes mastitis in bovine.

\section{Introduction}

Mastitis is the most economically significant disease of dairy animals. This condition is widespread in dairy herds and is associated with a significant reduction in milk yield, increased costs of production and deteriorated milk quality. These costs are borne directly by milk producers and indirectly by the consumers of dairy products.

The disease also results in partial or complete damage to udder tissues and decreases the productive life span of the animal.
Mastitis is caused by many bacteria, which include the coliform group (Specifically Escherichia coli, Enterobacter, Klebsiella species), Streptococci, Staphylococci, Corynebacteria, Pasteurella, Mycoplasma, Leptospira, Yersinia, Mycobacteria, Psuedomonas, Serratia and other organisms like fungi, yeasts and virus (Burns et al., 1996).

Escherichia coli (E. coli) is a Gram negative bacteria belonging to Family Enterobacteriacea. E. coli is a rod-shaped member of the coliform group, can be 
distinguished from most other coliforms by its ability to ferment lactose at $44^{\circ} \mathrm{C}$, and by its growth and color reaction on certain types of culture media. It is the lactose fermenter and produces pink colonies in Macconkey agar. When cultured on an EMB plate, a positive result for E.coli is a metallic green media with dark purple colonies (Kavitha and Devasena, 2013).

The aim of this study was to isolate and biochemical characterization of Escherichia coli from bovine mastitic milk.

\section{Materials and Methods}

\section{Collection of samples}

A total of 100 bovine mastitis milk samples were collected from the dairy herd farms in and around Bidar. All the samples were subjected to bacteriological isolation.

\section{Isolation of $E$. coli}

\section{Inoculation into broth}

In the laboratory the milk sample was inoculated into tryptose soy broth under sterile condition. After inoculation, the test tube was incubated at $37^{\circ} \mathrm{C}$ for overnight. (Cruickshank et al., 1975) The suspected colonies were transformed onto MacConkey's agar and EMB agar. The inoculated plates were incubated for 24-48 hours at $37^{\circ} \mathrm{C}$. Suspected colonies were confirmed primarily as Gram-negative rods (Cruickshank et al., 1975).

\section{Identification of $E$. coli}

The pure colonies subjected for biochemical test using Indole test, Methyl red test Sugar fermentation reaction, Citrate utilization test and Voges-Proskauer test (Kavitha and Devasena, 2013).

\section{Results and Discussion}

100 Milk samples were collected from mastitis affected bovine. The samples were inoculated in Triptose soya broth, After an incubation period of 4-6 hours, the samples were streaked on differential media namely Mac Conkey agar and Eosine Methylene blue agar.

\section{Eosin Methylene Blue agar (EMB)}

Eosin Methylene Blue (EMB) Agar is used for identification of microorganism. E. coli produced Metallic sheen colour colonies in Eosin Methylene Blue (EMB) Agar. In the present study 42 isolates which produced Metallic Sheen colour colonies indicating the presence of E. coli (Fig. 1).

\section{MacConkey agar}

Mac conkey agar is used to isolate coliform. If the organism is coliform they 100 Mastitis milk samples collected, 42 samples were produced ink colour colony indicating the presence of coliform (Fig. 2).

\section{Gram staining}

Gram staining is used for identification of Gram positive and Gram negative organism. E.coli is a gram negative rod Shaped bacterium. In the present study the 42 isolates were subjected to gram staining all the isolates were found to be gram negative rods.

\section{Biochemical characterization}

All suspected colonies of E.coli on the basis of cultural and morphological properties were subjected to biochemical tests (Fig. 3 to 6). Indole test, Methyl red test Sugar fermentation reaction, Citrate utilization test and VogesProskauer test. 42 isolates were confirmed to be $E$. coli after the biochemical results. 


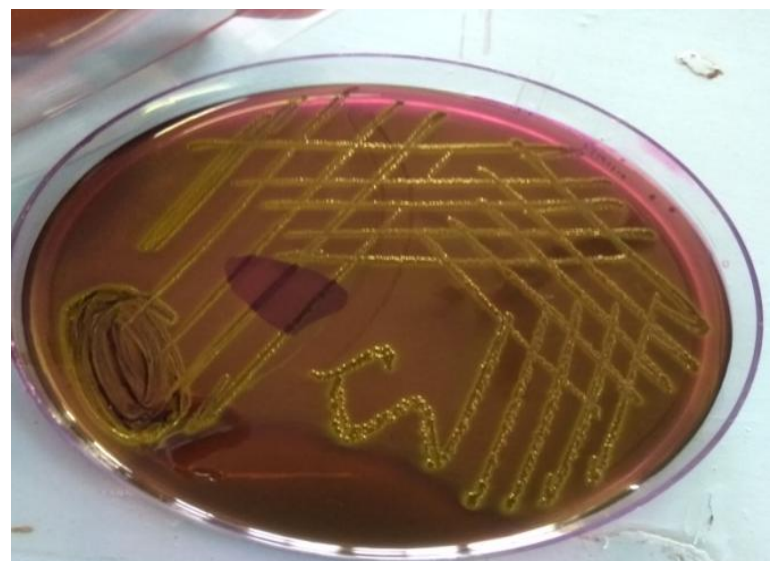

Fig.1 Eosine Methylene blue agar

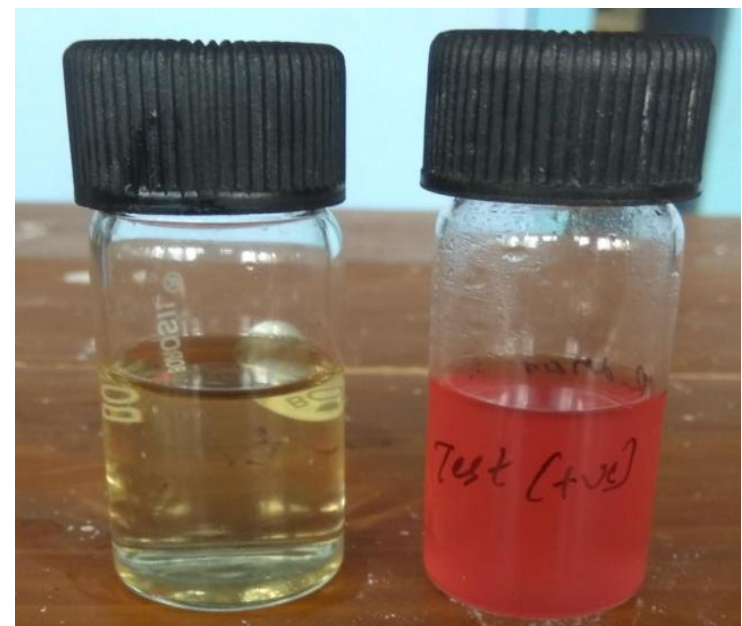

Fig.3 Methyle red test

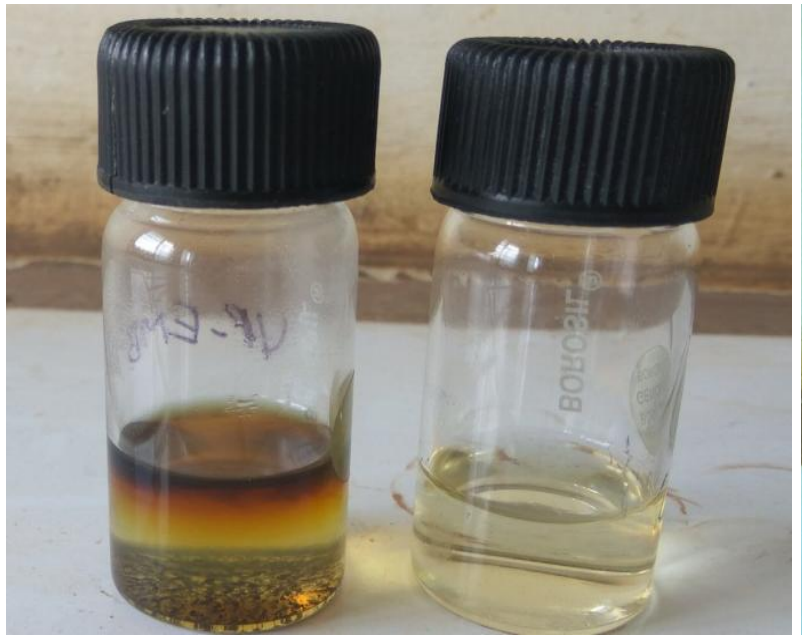

Fig.5.Voges-Proskauer test

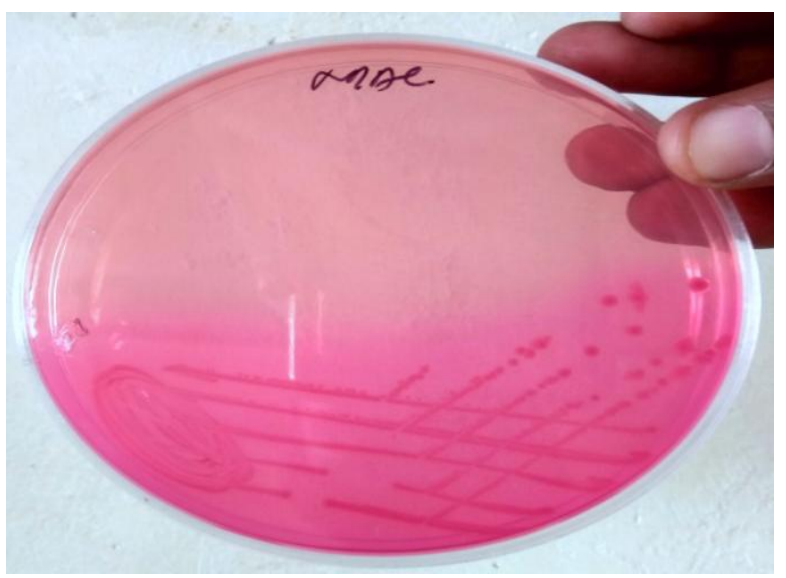

Fig.2 MacConkey agar

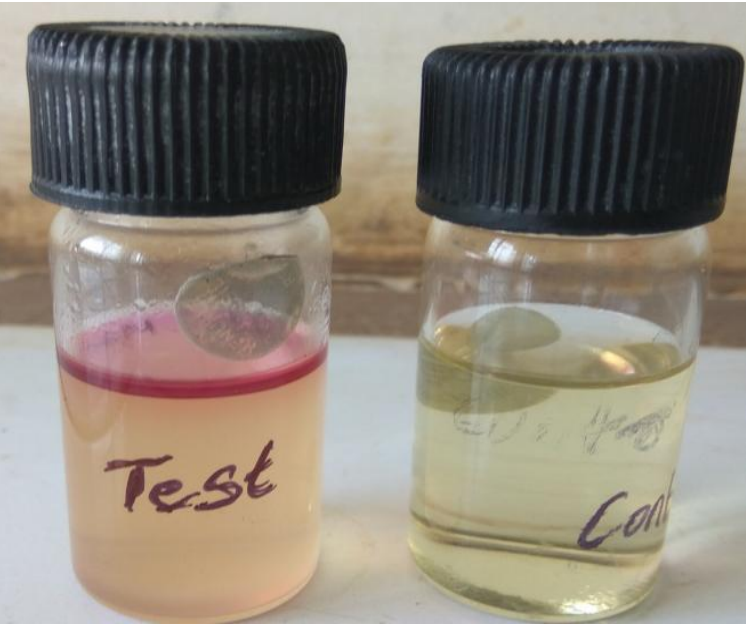

Fig.4 Indole test

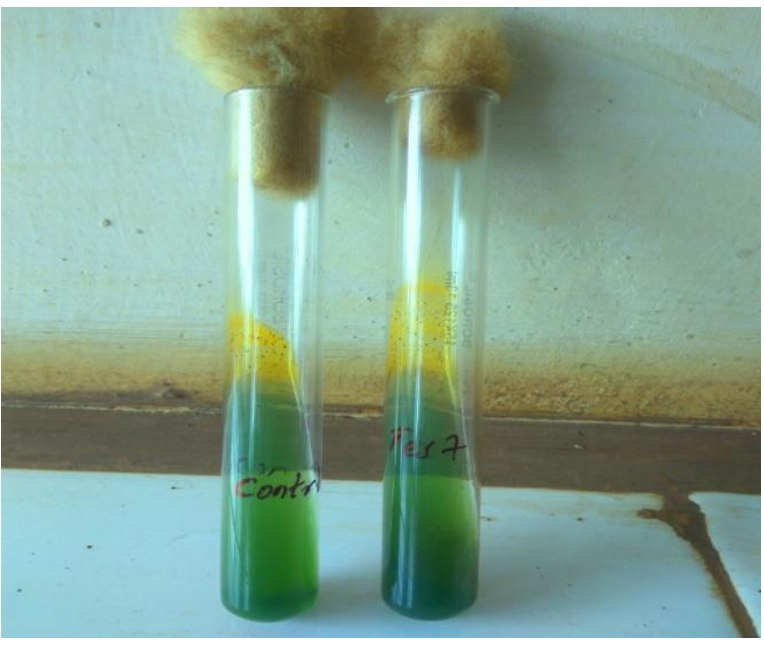

Fig.6 Citrate utilization test 
Therefore the basis of cultural characteristics and biochemical reaction 40 were confirmed to be E.coli (Kavitha and Devasena, 2013).

To conclude, the Coliform mastitis is caused by a group of coliform organisms. E.coli is one of the most important bacterium of coliform group that causes mastitis in bovine. E.coli isolates were isolated by culturing in Eosine Methylene blue agar and in Mac Conkey agar. The isolates were confirmed by different Biochemical Tests.

\section{Acknowledgement}

Authors are thankful for Department of Veterinary Microbiology, Veterinary college Bidar. Karnataka Veterinary Animal Fisheries science University Bidar, Karnataka (India).

\section{References}

Adwan K., Abu-Hasan., Essawi T and Bdir M 2002. Isolation and characterization of Shiga toxigenic Escherichia coli strains from northern Palestine, Journal of Medical Microbiology, 51 (4); 332 335.

Ahmed, AM and S.S. Sailam 1991. Prevalence of E.coli serotypes in raw milk and some dairy products. Vet. Med.J., 25: $93-97$.

Bean. A, Williamson. J and Cursons R.T. 2004. Virulence Genes of Escherichia coli Strains Isolated from Mastitic Milk, Journal of Veterinary Madicine Series B. 51 (6), $285-287$.

Bradley A.J. Bovine Mastitis: 2005 An Evolving Disease, The Veterinary Journal 164, 116 - 128.

Burvenich, C., Van merris, V., Merhzad, J.,
Diez-fraile, A. and Duchateau, L. 2003. Severity of $E$. coli mastitis is mainly determined by cow factors. Vet. Res. 34: $521-564$

Burns, A.L. Ball, H.J. and Finlay, D.A. 1996 CNF producing Escherichia coli isolated from cattle in Northern Ireland. Vet Microbiol. 49: 235 - 241

Carroll, E.J. Jain, N.C., Schalm, O.W. and Lasmanis, J. 1973. Experimentally induced coliform mastitis: Inoculation of udders with serum - sensitive and serum - resistant organisms. Am. J. Vet. Res. 34: 1143 - 1146.

Cruickshank R., Duguid J.P., Marmion B.P. and Swain R.H.A. 1975. Medical Microbiology Vol. II, 12th edn, Crurchill Living stone, New York, Pp. 31-57 and 96-218.

Eberhart, R.J., 1977. Coliform Mastitis. J. Am. Vet. Assoc., 170: 1160-1163.

J.R.Kavitha and T. Devasena. 2013. Molecular and Bacteriological examination of cow milk in coliform mastitis. J.Pharmay and Biological Science.,6(2):23197676.

Kaper, J.B., J.P. Nataro and H.L.T. Mobley, 2004.Pathogenic Escherichia coli. Nat. Rev. Microbiol., 2:123-140.

Suojala L., Pohjanvirta T., Simojoki H., Myllyniemi A. L., Pitkala A., Pelkonen S. and Pyorala S. 2011. Phylogeny, virulence factors and antimicrobial susceptibility of Escherichia coli isolated in clinical bovine mastitis. Veterinary Microbiology 147(3): 383 388.

Watts, J.L. 1988. Etiological agents of bovine mastitis. Veterinary Microbiology 16: 41-66.

\section{How to cite this article:}

Paramesh, B.N., A. Basavaraj, P. Suryakanth, B. Abhilash and Revappayya, M. 2018. Isolation and Biochemical Characterization of Escherichia coli from Bovine Mastitic Milk. Int.J.Curr.Microbiol.App.Sci. 7(07): 719-722. doi: https://doi.org/10.20546/ijcmas.2018.707.086 